\title{
CHANGES IN AMINO ACID PROFILE OF CORD BLOOD PLASMA AND AMNIOTIC FLUID OF MOTHERS WITH COVID-19
}

\author{
Lomova NA $\bowtie$, Chagovets W, Dolgopolova EL, Novoselova AV, Petrova UL, Shmakov RG, Frankevich VE
}

National Medical Research Center for Obstetrics, Gynecology and Perinatology named after Academician V. I. Kulakov, Moscow, Russia

\begin{abstract}
Neonates born to mothers with COVID-19 are at risk for infection, they may have high risk of complications during the neonatal period, and long-term health consequences. The study was aimed to define the amino acid profile of blood plasma and amniotic fluid in patients with COVID-19 in order to assess the relationship between the COVID-19 infection during the antenatal period, and metabolomic alterations in the "intrauterine" patient. The levels of 31 amino acids in the samples of amniotic fluid and cord blood plasma of pregnant women with COVID-19, obtained during delivery, were assessed by high-performance liquid chromatography-mass spectrometry. The index group included 29 patients with confirmed diagnosis of COVID-19, and the control group included 17 healthy women with uncomplicated pregnancies. There were significant $(p<0.05)$ differences in the concentrations of eight amino acids between the studied groups. Logistic regression models were developed (sensitivity 0.84 ; specificity 1 ) making it possible to define, whether the assessed amniotic fluid was obtained from COVID-19 patients. Significant differences in the concentrations of four amino acids were observed in the umbilical cord blood. The models developed made it possible to define whether the studied cord blood plasma belonged to controls or to COVID-19 patients (sensitivity and specificity 1). Three amino acids were detected, and their levels were significantly different in COVID-19 patients simultaneously in two points (amniotic fluid and cord blood plasma), depicting the fetal metabolome in a holistic manner. The impact of the virus on those infected results in pronounced metabolomic alterations in the amniotic fluid and the fetal cord blood plasma, which may lead to impaired programming of protein production, but never show up at birth.
\end{abstract}

Keywords: amino acid analysis, cord blood plasma, amniotic fluid, COVID-19, markers of neonatal condition

Funding: the study was supported by RFBR grant №. 20-04-60093.

Author contribution: Lomova NA — analysis of clinical data, systematic analysis, manuscript writing; Chagovets W — mass spectrometry-based metabolome analysis, statistical analysis of the results, manuscript editing; Dolgopolova EL — collection and preparation of biological matrix samples in the red zone, statistical analysis of the results; Novoselova AV — mass spectrometry-based metabolome analysis, mass spectrometry data processing; Petrova UL — collection and preparation of biological matrix samples in the red zone; Shmakov RG — analysis of clinical data in the red zone, systematic analysis, manuscript editing; Frankevich VE - preparation of the study, systematic analysis, manuscript writing and editing.

Compliance with ethical standards: the study was approved by the Ethics Committee of the National Medical Research Center for Obstetrics, Gynecology and Perinatology named after Academician V. I. Kulakov (protocol № 13 dated December 10, 2020); the study met the requirements of the Declaration of Helsinki, International Conference on Harmonization (ICF), Good Clinical Practice (GCP), and Federal Law No. 323-FZ "On the Basics of Protecting Citizens' Health in the Russian Federation" of November 21, 2011; the informed consent was submitted by all patients.

$\triangle$ Correspondence should be addressed: Natalia A. Lomova

Oparina, 4, Moscow, 117997; natasha-lomova@yandex.ru

Received: 24.05.2021 Accepted: 18.06.2021 Published online: 29.06.2021

DOI: $10.24075 / \mathrm{brsmu} .2021 .032$

\section{ИЗМЕНЕНИЕ АМИНОКИСЛОТНОГО ПРОФИЛЯ ПЛАЗМЫ ПУПОВИННОЙ КРОВИ И АМНИОТИЧЕСКОЙ ЖИДКОСТИ ОТ МАТЕРЕЙ С COVID-19}

\author{
Н. А. Ломова 凶, В. В. Чаговец, Е. Л. Долгополова, А. В. Новоселова, У. Л. Петрова, Р. Г. Шмаков, В. Е. Франкевич
}

Национальный медицинский исследовательский центр акушерства, гинекологии и перинатологии имени В. И. Кулакова, Москва, Россия

Новорожденные от матерей с COVID-19 подвержены риску заражения, могут иметь высокий риск осложнений в раннем неонатальном периоде и отдаленные последствия для здоровья. Цель исследования - определить аминокислотный профиль пуповинной плазмы и амниотической жидкости пациентов с COVID-19 для анализа связи влияния перенесенного антенатально COVID-19 на изменения в метаболоме «внутриутробного пациента». Для оценки уровня 31 аминокислоты в образцах амниотической жидкости и пуповинной плазмы беременных с COVID-19, полученных при родоразрешении, применяли высокоэффективную жидкостную хроматографию с масс-спектрометрической детекцией. Основную группу составили 29 пациенток с подтвержденным диагнозом COVID-19; контрольную - 17 соматически здоровых женщин с беременностью без осложнений. Концентрации восьми аминокислот в амниотической жидкости статистически значимо ( $<0,05)$ различались между исследуемыми группами. Разработаны модели логистической регрессии (чувствительность 0,84; специфичность - 1), позволяющие определять, что анализируемая амниотическая жидкость взята от пациенток, перенесших COVID-19. В плазме пуповинной крови значимые различия обнаружены для четырех аминокислот. Построенные модели позволяют выявлять принадлежность исследуемой пуповинной плазмы пациентам группы контроля или COVID-19 (чувствительность и специсичность - 1). Одновременно в двух точках (амниотическая жидкость и пуповинная плазма), комплексно отображающих метаболом плода, были выявлены и статистически значимо отличались при COVID-19 три аминокислоты. Воздействие вируса на организм приводит к выраженным изменениям в метаболоме амниотической жидкости и пуповинной плазмы плода, что может привести к нарушению программирования производства белковых молекул, но не проявляется при рождении.

Ключевые слова: аминокислотный анализ, плазма пуповинной крови, амниотическая жидкость, COVID-19, маркеры состояния новорожденного

Финансирование: работа выполнена при финансовой поддержке РФФИ грант рег. № 20-04-60093.

Вклад авторов: Н. А. Ломова - анализ клинических данных, систематический анализ, написание рукописи; В. В. Чаговец — проведение метаболомного анализа методом масс-спектрометрии, статистический анализ полученных данных, редактирование рукописи; Е. Л. Долгополова — сбор и подготовка биологических сред в условиях «красной зоны», статистический анализ результатов; А. В. Новоселова - проведение метаболомного анализа методом масс-спектрометрии, обработка масс-спектрометрических данных; У. Л. Петрова - сбор и подготовка биологических сред в условиях «красной зоны»; Р. Г. Шмаков - анализ клинических данных в условиях «красной зоны», систематический анализ, редактирование рукописи; В. Е. Франкевич подготовка исследования, систематический анализ, написание и редактирование рукописи.

Соблюдение этических стандартов: исследование одобрено этическим комитетом НМИЦ АГП им. В. И. Кулакова (протокол № 13 от 10 декабря 2020 г.), проведено в соответствии с требованиями Хельсинкской декларации, Международной конференции по гармонизации (ICF), Стандартов надлежащей клинической практики (GCP), Ф3 № 323-Ф3 от 21 ноября 2011 г. «Об основах охраны здоровья граждан в Российской Федерации»; все пациентки подписали добровольное информированное согласие на участие в исследовании.

$\triangle$ Для корреспонденции: Наталья Анатольевна Ломова

ул. Академика Опарина, д. 4, г. Москва, 117997; natasha-lomova@yandex.ru

Статья получена: 24.05.2021 Статья принята к печати: 18.06.2021 Опубликована онлайн: 29.06.2021

DOI: $10.24075 /$ vrgmu.2021.032 
The outbreak of severe acute respiratory syndrome, caused by SARS-CoV-2 coronavirus, emerged in Wuhan (China) in 2019 and quickly led to global pandemic, which forced the countries' healthcare systems to provide intensive care to a huge number of patients. The number of cases around the world is increasing every day due to rapid spread of the infection. Currently, only in Russia a total of 4,700,000 confirmed cases of COVID-19 infection have been registered. Pregnant women are a vulnerable population, susceptible to COVID-19 infection due to physiological changes in immunological and blood circulation parameters. Infants, born to mothers infected with COVID-19, are at risk of infection, as well as at high risk of complications during the early neonatal period, and long-term health consequences. Specific consequences of COVID-19 have not yet been studied, however, studies of influenza virus suggest the possibility of such consequences [1, 2]. To date, little is known about perinatal and neonatal COVID-19 infection, and the available information is largely based on the single case reports. One of the earliest and largest studies involved 33 neonates born to mothers with confirmed diagnosis of COVID-19 [3]. Several viral transmission modes were postulated, such as postnatal transmission (horizontal), transplacental transmission, and transmission via amniotic fluid and breast milk [4-12]. The first study describing the clinical features and aimed at investigation of the SARS-CoV-2 vertical transmission possibility in nine pregnant women with laboratory confirmed COVID-19, showed no evidence of vertical transmission [11, 13]. More recently, however, the reports have been published of vertical viral transmission sporadic cases, as well as of severe disease in pregnant women during the antenatal period [14, 15]. Thus, transplacental transmission of the virus has been demonstrated, confirmed by complex virologic testing of placenta, as well as by symptoms and clinical manifestations in newborns [16].

Due to the fundamental reasons, metabolome is a more sensitive and dynamic indicator of cell and body biochemical status, than proteome or transcriptome [17]. Metabolomic analysis of samples obtained from COVID-19 patients enables investigation of biochemical alterations associated with poorly understood pathways, since it demonstrates the effects of the virus on the host instead of just the presence of the infectious agent. Metabolomic research can provide a number of markers, being potentially important for SARS-CoV-2 infection confirmation, as well as for evaluation of the disease severity and possible outcome. Recently it has been shown that plasma levels of 204 metabolites in COVID-19 patients correlate with the disease severity [18]. Amino acids that are part of metabolome are essential for all human life processes. Biological role of about 300 amino acids in the human body is invaluable. The body cannot develop effectively without the sufficient amounts of amino acids. That is why there are optimal levels of amino acids, which ensure the metabolic balance. Inconsistence of amino acid concentrations with reference values can be indicative of certain disorders. Thus, amino acid concentrations change in individuals with sand fly fever virus infection [19], pneumonia, caused by H1N1 influenza virus [20], and chronic obstructive pulmonary disease [21]. A number of neonatal diseases are detected by amino acid assessment in the dried blood spot specimens [22]. In recent years, the assessment of the smallmolecule intermediates of metabolic pathways in the biological systems is becoming increasingly important, since it facilitates understanding of human metabolic pathways interaction and regulation. The disease-related alterations in metabolic profiles of human physiological fluids are studied in order to clarify the complex disorders pathophysiology. For example, metabolomic analysis has shown that alterations in amino acid metabolism correlate with altered oxygen homeostasis in COVID-19 patients [23]. Another study of amino acid profiles in children and adults has revealed alterations, which can be associated with endothelial dysfunction and T-cell dysregulation [24]. Various metabolic pathways can be described by measuring amino acid concentrations [25].

Thus, the study was aimed to determine the effects of COVID-19 on the amino acid composition of amniotic fluid and cord blood plasma in order to develop the diagnostic panel, and to determine the impact of possible amino acid metabolism alteration consequences on the condition of newborns.

\section{METHODS}

From March to May 2020 in the National Medical Research Center for Obstetrics, Gynecology and Perinatology named after Academician V. I. Kulakov the "red zone" was established for examination and treatment of patients with COVID-19, pregnant women among them. A total of 190 beds for patients with COVID-19 and 60 beds for obstetric patients were prepared.

A total of 46 pregnant women were enrolled, who were admitted to and gave birth at the National Medical Research Center for Obstetrics, Gynecology and Perinatology named after Academician V. I. Kulakov. The index group included 29 patients with confirmed diagnosis of COVID-19; the control group included 17 healthy women with uncomplicated pregnancies. The diagnosis of COVID-19 was confirmed by PCR test (DNA-Technology; Russia). The patients were included in the group subsequent to their admission. Inclusion criteria for group I: COVID-19 based on the molecular genetic analysis data (PCR); inclusion criteria for group II: no COVID-19 based on the physical examination data and PCR test results. Exclusion criteria: multiple pregnancy; no Rhesus (Rh) or $\mathrm{ABO}$ isoimmunization, chromosomal abnormalities, genetic mutations, and congenital malformations in the fetus. Cord blood plasma and amniotic fluid were sampled for analysis.

Biological fluids were sampled in all patients at the $1^{\text {st }}$ Infectious Diseases Department of the National Medical Research Center for Obstetrics, Gynecology and Perinatology named after Academician V. I. Kulakov, the "red zone", followed by sample preparation and storage. Transportation and subsequent analysis were performed within the territory of the National Medical Research Center for Obstetrics, Gynecology and Perinatology named after Academician V. I. Kulakov in the rooms certified for operating hazard class 2 samples. Standard kit and modified protocol were used for sample preparation and subsequent analysis of 31 amino acids in physiological fluids (JASEM; Turkey). The kit contained two different calibration mixtures of lyophilized amino acids, mixture of internal standards, lyophilized mixture for quality control, mobile phases A and B, Reagent 1 (part number JSM-CL-503), used for plasma sample preparations, and the column for highperformance liquid chromatography (HPLC) of amino acids (part number JSM-CL-575).

During preparation for analysis, $50 \mu \mathrm{L}$ of sample were mixed with $50 \mu \mathrm{L}$ of the internal standard solution, stirred for $5 \mathrm{~s}$, added $700 \mu \mathrm{L}$ of Reagent 1 , stirred again for $15 \mathrm{~s}$, and centrifuged at 3000 RPM for 3 minutes. After that, supernatant fluid was transferred into chromatography vial. Samples and auxiliary solutions were prepared and stored in accordance with the JASEM manual.

Samples were analyzed by high-performance liquid chromatography-mass spectrometry using the 1260 Infinity II 
Table 1. Clinical characteristics of pregnant women with COVID-19

\begin{tabular}{|l|r|}
\hline \multicolumn{1}{|c|}{ Clinical characteristics } & COVID-19 $(n=29, \%)$ \\
\hline Symptoms & $21(71.41)$ \\
\hline Hyperthermia $\left(>37^{\circ} \mathrm{C}\right)$ & $12(41.38)$ \\
\hline Loss of smell & $7(24.14)$ \\
\hline Sore throat & $3(10.34)$ \\
\hline Shortness of breath & $4(13.79)$ \\
\hline Cough & $12(41.38)$ \\
\hline Fatigue & $4(13.79)$ \\
\hline Mild course & $22(75.86)$ \\
\hline Moderate course & $6(20.69)$ \\
\hline Severe course & $1(3.45)$ \\
\hline
\end{tabular}

HPLC system (Agilent; USA) and the 6460 Triple Quad mass spectrometer system (Agilent; USA).

Transitions from parent ions to daughter fragments for the assayed amino acids, corresponding chromatography retention time values, internal standard concentrations, as well as data on the analysis sensitivity and reproducibility, are presented in the JASEM manual.

\section{Statistical analysis}

Statistical data processing was performed using scripts written in R language (R Core Team, Vienna, Austria, and Rstudio; R. RStudio, Inc.; Boston).

Statistical analysis was carried out using the nonparametric Mann-Whitney $U$ test. Quantitative data were described using median $(\mathrm{Me})$ and quartiles $Q_{1}$ and $Q_{3}$ in the Me format $\left(Q_{1} ; Q_{3}\right)$. The threshold of significance, $p$-value, was 0.05 . When $p$-value was less than 0.001 , it was reported as $p<0.001$.

The logistic regression models were developed in order to assess whether the patients could be classified into groups based on the studied parameters. All possible combinations of amino acids were treated as dependent variables. The patient's belonging to certain group was considered an independent variable. Four models with maximum area under the ROC curve (AUC) were selected among the developed models. Wald criterion, 95\% confidence interval $(95 \% \mathrm{Cl})$, odds ratio (OR) and its confidence interval were defined for each model. The quality of models developed was defined by constructing the ROC curve, calculating the area under the ROC curve, as well as by defining sensitivity and specificity.

\section{RESULTS}

A total of 46 women were enrolled: of them 29 patients were admitted to hospital because of confirmed COVID-19, and

Table 2. Clinical characteristics of pregnant women enrolled
17 patients had no viral infection (control group). The average age of the patients was $30.7 \pm 4.9$ years: $29.9 \pm 5.03$ years in group 1, and $32.0 \pm 5.03$ in the control group. There were no significant differences in the body mass index between two groups: it was $27.85 \pm 4.52$ in the first group, and $26.12 \pm 3.16$ in the second group.

The major clinical manifestations were as follows: cough (41.38\%), loss of smell (24.14\%), and hyperthermia (41.38\%) (Table 1). Asymptomatic COVID-19 was observed in 8 patients (28.59\%). Patients with mild, moderate and severe course of the disease accounted for 22 (75.86\%), 6 (20.69\%), and 1 (3.45\%) case respectively.

Computed tomography (CT) revealed no typical features of viral pneumonia in $25 \%$ of cases (CT 0). High probability of viral pneumonia with minimum lung tissue involvement was revealed in $40 \%$ of women (CT 1). High probability of viral pneumonia with $25-50 \%$ lung tissue involvement (CT 2) was observed in $10 \%$ of women. High probability of viral pneumonia with 50-75\% lung tissue involvement (CT 3) was revealed in $10 \%$ of patients; critical lung tissue involvement (> 75\%, CT-4) was observed in $15 \%$ of cases.

In the group of patients with confirmed COVID-19, the delivery time of $38 \pm 1.52$ weeks of pregnancy was significantly different from that of the controls $(39.42 \pm 1.14$ weeks, $p=0.001)$. Probably this has something to do with four (13.8\%) cases of preterm labor in the group with COVID-19; however, the cause of premature birth was not related to COVID-19 infection severity. In one case, preterm labor resulted from illpreparedness of soft birth canal and the scarred uterus, in the other case it resulted from increasing severity of preeclampsia, and in two more cases it resulted from preterm prelabor rupture of membranes, and labor onset. Cesarean section was performed in 13 patients (44.8\%) (RR: 0.9 [0.5; 1.6]), vacuum extraction due to fetal distress was performed in one patient (3.5\%); other patients had normal vaginal delivery. In the control

\begin{tabular}{|l|c|c|c|}
\hline & COVID-19 $(n=29)$ & Controls $(n=17)$ & $p$ \\
\hline Age, years & $29.9( \pm 5.03)$ & $32.0( \pm 5.03)$ & 0.16 \\
\hline Height, $\mathrm{cm}$ & $166.62( \pm 7.37)$ & $165.76( \pm 7.34)$ & 0.71 \\
\hline Weight, $\mathrm{kg}$ & $77.64( \pm 11.58)$ & $71.87( \pm 9.75)$ & 0.10 \\
\hline BMI & $27.85( \pm 4.52)$ & $26.12( \pm 3.16)$ & 0.18 \\
\hline Delivery time, months & $38( \pm 1.52)$ & $39.42( \pm 1.14)$ & 0.001 \\
\hline Baby's birth weight, $\mathrm{S}$ & $3332( \pm 484)$ & $3585( \pm 424)$ & 0.08 \\
\hline Baby's birth length, cm & $52.4( \pm 2.66)$ & $53.1( \pm 2.29)$ & 0.35 \\
\hline Apgar score at one minute of age & $8(8 ; 8)$ & $9(9 ; 9)$ & 0.69 \\
\hline Apgar score at five minutes of age & $8(8 ; 8)$ & $9(9 ; 9)$ & 0.83 \\
\hline
\end{tabular}


Table 3. Amino acid concentrations $(\mathrm{nmol} / \mathrm{mL})$ in amniotic fluid of controls and COVID-19 patients

\begin{tabular}{|c|c|c|c|}
\hline Amino acid & Controls & COVID-19 & $p$-value \\
\hline 1-methyl-L-histidine & $9.52(5.78 ; 23.54)$ & $0(0 ; 4.98)$ & $<0.001$ \\
\hline 3-methyl-L-histidine & $1.32(0.14 ; 2.56)$ & $1.62(0.48 ; 5.35)$ & 0.258 \\
\hline 3-aminoisobutyric acid & 7.44 (6.38; 9.22) & $5.48(4.4 ; 6.17)$ & 0.002 \\
\hline DL-5-hydroxylysine & $10.31(9.98 ; 10.69)$ & $10.28(9.99 ; 10.5)$ & 0.591 \\
\hline Ethanolamine & $45.69(38.94 ; 67.65)$ & $35.24(24.53 ; 46.3)$ & 0.096 \\
\hline L-2-aminobutyric acid & $1.5(1.27 ; 2.34)$ & $1.27(1 ; 2.62)$ & 0.367 \\
\hline L-2-aminoadipic acid & $7.21(5.39 ; 10.59)$ & $6.66(5.24 ; 9.46)$ & 0.615 \\
\hline L-alanine & 238.74 (179.29; 329.59) & 187.36 (136.91; 257.72) & 0.302 \\
\hline L-arginine & $26.59(22.42 ; 48.86)$ & $16.25(8.97 ; 23.61)$ & 0.006 \\
\hline L-asparagine & $29.36(24.49 ; 40.74)$ & $25.56(19.32 ; 41.31)$ & 0.391 \\
\hline L-aspartic acid & $13.82(7.9 ; 29.75)$ & $11.92(6.64 ; 62.9)$ & 0.784 \\
\hline L-carnosine & $4.58(4.43 ; 5.21)$ & $5.5(4.54 ; 6.31)$ & 0.107 \\
\hline L-citrulline & $8.6(6.93 ; 11.43)$ & $7.57(4.84 ; 14.52)$ & 0.632 \\
\hline L-cystathionine & $0.96(0.83 ; 1.16)$ & $0.8(0.56 ; 0.96)$ & 0.036 \\
\hline L-cystine & 39.69 (30.93; 46.09) & $15.92(5.48 ; 35.06)$ & 0.005 \\
\hline L-glutamic acid & $176.3(114.37 ; 215.51)$ & $112.92(67.26 ; 176.17)$ & 0.15 \\
\hline L-glutamine & 392.48 (267.94; 450.24) & 286.57 (177.62; 369.67) & 0.044 \\
\hline L-glycine & 216.37 (189.39; 359.66) & 219.92 (156.65; 260.22) & 0.43 \\
\hline L-histidine & $65.35(34.72 ; 85.64)$ & $7.9(0 ; 30.68)$ & 0.008 \\
\hline L-lysine & $153.56(113.59 ; 169.06)$ & 149.15 (105.52; 187.74) & 0.973 \\
\hline L-methionine & $16.55(10.59 ; 20.68)$ & $11.21(7.36 ; 19.59)$ & 0.252 \\
\hline L-ornithine & 24.16 (15.39; 34.42) & $42.8(20.11 ; 69.65)$ & 0.096 \\
\hline L-phenylalanine & 39.63 (24.82; 51.44) & $32(21.48 ; 55.77)$ & 0.515 \\
\hline L-proline & $118.37(103.97 ; 154.61)$ & $109.16(72.85 ; 125.35)$ & 0.137 \\
\hline L-serine & $65.52(37.24 ; 89.78)$ & $50.74(32.72 ; 95.85)$ & 0.681 \\
\hline L-threonine & $150.1(101.89 ; 211.52)$ & $136.31(96.46 ; 172.32)$ & 0.445 \\
\hline L-tryptophan & $11.63(7.7 ; 13.69)$ & 7.49 (4.36; 14.33) & 0.302 \\
\hline L-tyrosine & $24.3(17.75 ; 38.24)$ & $18.23(8.22 ; 47.62)$ & 0.435 \\
\hline L-valine & 378.17 (286.06; 544.61) & 412.5 (256.16; 570.82) & 0.681 \\
\hline Taurine & $12.6(11.48 ; 14.32)$ & $12.66(11.54 ; 16.48)$ & 0.958 \\
\hline Trans-4-hydroxy-L-proline & $18.03(14.18 ; 20.08)$ & $13.54(11.05 ; 15.96)$ & 0.019 \\
\hline
\end{tabular}

group, cesarean section was performed in 9 patients (52.9\%); other patients had normal vaginal delivery. The reasons for cesarean section were as follows: one or more uterine scars, fetal malpresentation, abnormal pelvic anatomy, and reports of other specialists (ophthalmologist, orthopedist, neurologist). In the group with COVID-19 the average birth weight was $3332 \pm 484 \mathrm{~g}$, and in the control groups it was $3585 \pm 424 \mathrm{~g}$; the average length of the newborns was $52.4 \pm 2.66 \mathrm{~cm}$ and $53.1 \pm 2.29 \mathrm{~cm}$ respectively. The newborns were assigned Apgar score $8(8 ; 8)$ at one minute and $9(9 ; 9)$ and five minutes of age in both groups (Table 2).

No cases of COVID-19 in newborns were registered. Newborns were isolated from their mothers immediately after birth. Breastfeeding was allowed after the mothers tested negative twice for SARS-CoV-2. All newborns were tested for SARS-CoV-2 immediately after birth, and then at three and 10 days of age. All newborns tested negative for the virus, which could indicate no vertical transmission of the infection. No perinatal deaths were registered.

During the laboratory phase, the targeted metabolomics approach was applied with the use of the kit for quantification of 31 amino acids by HPLC-MS in the samples of amniotic fluid and cord blood plasma, collected at the National Medical Research Center for Obstetrics, Gynecology and Perinatology named after Academician V. I. Kulakov. The study was performed in order to describe the levels of amino acids in neonates born to mothers, who tested positive for COVID-19.

\section{Amniotic fluid}

Concentrations of 31 amino acids were defined during the analysis of amniotic fluid. Statistical analysis of experimental data made it possible to identify eight amino acids, the levels of which were significantly different in patients with COVID 19 (Table 3; Fig. 1): 1-methylhistidine, 3-methylhistidine, arginine, cystathionine, cystine, glutamine, histidine, trans-4hydroxyproline.

In view of the HPLC-MS results obtained, of particular interest was the feasibility of developing mathematical model, allowing us to distinguish amniotic fluid samples obtained from COVID-19 patients and controls. For that, logistic regression models were constructed based on the amino acids showing 
A

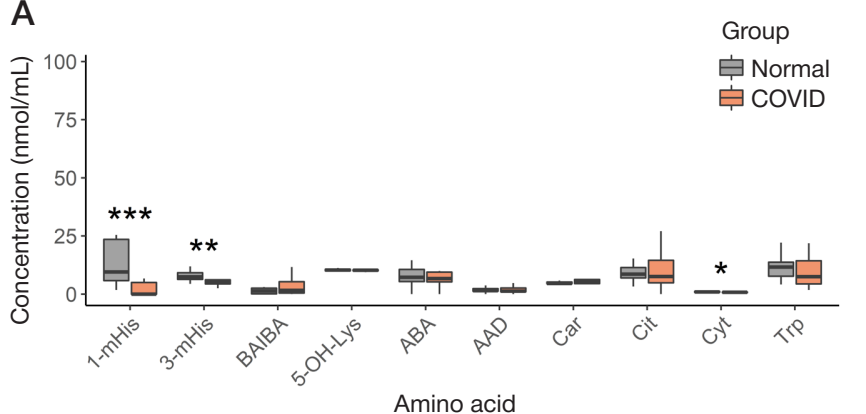

C

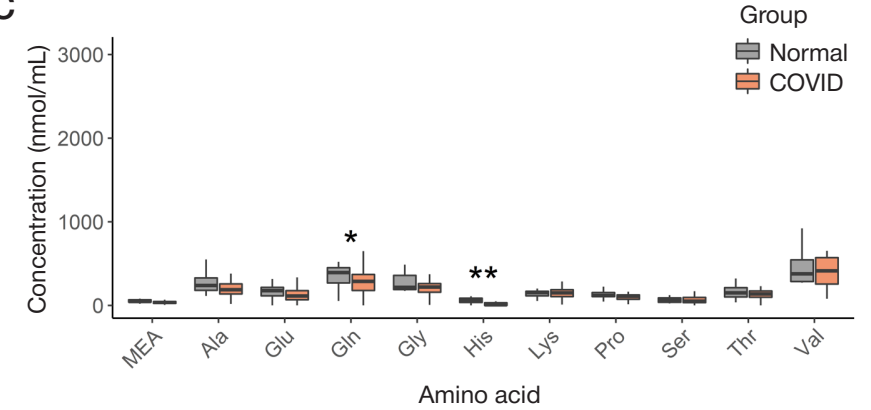

Amino acid
B

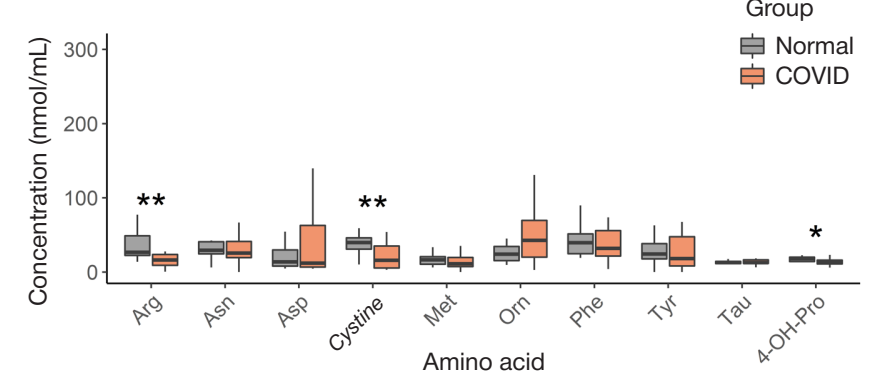

官 Normal COVID

Fig. 1. Amino acid concentrations in amniotic fluid of controls and COVID-19 patients. The first and the third quartiles form the boundaries of the box, the median is shown as a line in the center of the box; the ends of whiskers represent the following: one and a half times interquartile range subtracted from the first quartile, sum of the third quartile and one and a half times interquartile range; ${ }^{*}-p \leq 0.05 ;{ }^{* *}-p \leq 0.01 ;{ }^{* \star *}-p \leq 0.001 ; 1$-mHis -1 -methylhistidine; 3 -mHis -3 -methylhistidine; BAIBA - 3-aminoisobutyric acid; 5-OH-Lys - 5-hydroxylysine; MEA — ethanolamine; ABA — 2-aminobutyric acid; AAD — 2-aminoadipic acid; Car — carnosine; Cit — citrulline; Cyt — cystathionine; 4-OH-Pro - 4-hydroxyproline

significant differences between the studied groups. All possible combinations of amino acids were used to construct the models. $\mathrm{ROC}$ analysis was performed, and four models with maximum area under the ROC curve (AUC) were selected for each model. Parameters of the models constructed are presented in Table 4, and the corresponding ROC curves are presented in Fig. 2. The maximum AUC value of 0.89 was calculated for the model, constructed based on arginine, cystine, histidine, and trans-4-hydroxyproline (Table 5). This model had sensitivity of 0.84 , and specificity of 0.93 . Slightly higher sensitivity and specificity ( 0.84 and 1 respectively) were calculated for the model, constructed based on 1-methylhistidine, cystine, and trans-4-hydroxyproline (Table 5).

\section{Cord blood plasma}

The cord blood plasma amino acid profiles were analyzed in two groups during the next phase of the study. Statistical analysis

Table 4. Parameters of logistic regression models allowing one to distinguish patients with COVID-19 from patients with no COVID-19 based on the amino acid concentrations in the amniotic fluid

\begin{tabular}{|c|c|c|c|c|c|c|c|c|c|}
\hline \multirow{2}{*}{ Model № } & \multirow{2}{*}{ Coefficient } & \multirow{2}{*}{ Coefficient value } & \multirow{2}{*}{$\begin{array}{c}\text { Wald } \\
\text { criterion }\end{array}$} & \multirow{2}{*}{$p$-value } & \multicolumn{2}{|c|}{$\mathrm{Cl}$} & \multirow{2}{*}{ OR } & \multicolumn{2}{|c|}{ OR } \\
\hline & & & & & $2.50 \%$ & $97.50 \%$ & & $2.50 \%$ & $97.50 \%$ \\
\hline \multirow{5}{*}{1} & Intercept term & 5.8782 & 2.3394 & 0.019 & 1.8187 & 11.8835 & 357.17 & 6.1637 & 144864 \\
\hline & L-arginine & 0.0091 & 0.3735 & 0.709 & -0.042 & 0.0565 & 1.0091 & 0.9588 & 1.0582 \\
\hline & L-cystine & -0.0842 & -2.2358 & 0.025 & -0.1747 & -0.0208 & 0.9192 & 0.8397 & 0.9794 \\
\hline & L-histidine & 0.0129 & 1.1644 & 0.244 & -0.0063 & 0.0386 & 1.013 & 0.9937 & 1.0394 \\
\hline & Trans-4-hydroxy-L-proline & -0.2534 & -1.7891 & 0.074 & -0.574 & -0.0041 & 0.7762 & 0.5633 & 0.9959 \\
\hline \multirow{4}{*}{2} & Intercept term & 2.7692 & 1.7238 & 0.085 & -0.1116 & 6.3699 & 15.9456 & 0.8944 & 583.996 \\
\hline & 1-methyl-L-histidine & -0.0336 & -1.271 & 0.204 & -0.1107 & 0.0073 & 0.9669 & 0.8952 & 1.0073 \\
\hline & L-cystine & -0.0123 & -0.5235 & 0.601 & -0.0621 & 0.0328 & 0.9878 & 0.9398 & 1.0333 \\
\hline & Trans-4-hydroxy-L-proline & -0.1114 & -1.0398 & 0.298 & -0.3392 & 0.0951 & 0.8946 & 0.7123 & 1.0998 \\
\hline \multirow{5}{*}{3} & Intercept term & 2.7231 & 1.6899 & 0.091 & -0.152 & 6.3672 & 15.2278 & 0.859 & 582.4 \\
\hline & 1-methyl-L-histidine & -0.0339 & -1.2824 & 0.2 & -0.1109 & 0.0071 & 0.9667 & 0.895 & 1.0071 \\
\hline & L-cystine & -0.0156 & -0.5326 & 0.594 & -0.0792 & 0.0395 & 0.9845 & 0.9239 & 1.0402 \\
\hline & L-glutamine & 7.00E-04 & 0.1925 & 0.847 & -0.0066 & 0.0082 & 1.0007 & 0.9934 & 1.0082 \\
\hline & Trans-4-hydroxy-L-proline & -0.116 & -1.0585 & 0.29 & -0.3503 & 0.0978 & 0.8905 & 0.7045 & 1.1027 \\
\hline \multirow{5}{*}{4} & Intercept term & 5.1861 & 2.146 & 0.032 & 1.2261 & 11.0587 & 178.765 & 3.408 & 63495.7 \\
\hline & 1-methyl-L-histidine & -0.0272 & -0.8762 & 0.381 & -0.1263 & 0.0193 & 0.9731 & 0.8813 & 1.0195 \\
\hline & L-cystine & -0.0633 & -1.6706 & 0.095 & -0.1559 & 8.00E-04 & 0.9387 & 0.8557 & 1.0008 \\
\hline & L- histidine & 0.0146 & 2.199 & 0.028 & 0.0032 & 0.0312 & 1.0147 & 1.0032 & 1.0317 \\
\hline & Trans-4-hydroxy-L-proline & -0.2185 & -1.5539 & 0.12 & -0.5408 & 0.0346 & 0.8038 & 0.5823 & 1.0352 \\
\hline
\end{tabular}


Table 5. Characteristics of logistic regression models allowing one to distinguish patients with COVID-19 from patients with no COVID-19 based on the amino acid concentrations in the amniotic fluid

\begin{tabular}{|c|c|c|c|c|c|}
\hline Amino acid & AUC & Threshold & Sensitivity & Specificity & $\begin{array}{c}\text { Positive predictive } \\
\text { value }\end{array}$ \\
\hline L-arginine, L-cystine, L-histidine, trans-4- hydroxy-L-proline & 0.89 & 0.46 & $0.84(0.58 ; 1)$ & $0.93(0.73 ; 1)$ & $0.94(0.8 ; 1)$ \\
\hline 1-methyl-L-histidine, L-cystine, trans-4- hydroxy-L-proline & 0.88 & 0.68 & $0.84(0.63 ; 1)$ & $1(0.8 ; 1)$ & $1(0.86 ; 1)$ \\
\hline 1-methyl-L-histidine, L-cystine, L-glutamine, trans-4- hydroxy-L-proline & 0.88 & 0.67 & $0.82(0.63 ; 0.95)$ & $1(0.87 ; 1)$ & $1(0.87 ; 1)$ \\
\hline 1-methyl-L-histidine, L-cystine, L- histidine, trans-4- hydroxy-L-proline & 0.88 & 0.65 & $0.79(0.58 ; 1)$ & $0.93(0.67 ; 1)$ & $0.95(0.78 ; 1)$ \\
\hline
\end{tabular}

Table 6. Amino acid concentrations ( $\mathrm{nmol} / \mathrm{mL}$ ) in cord blood plasma of controls and COVID-19 patients

\begin{tabular}{|c|c|c|c|}
\hline Amino acid & Controls & COVID-19 & $p$-value \\
\hline 1-methyl-L-histidine & $0(0 ; 1.95)$ & $0(0 ; 0)$ & 0.041 \\
\hline 3-methyl-L-histidine & $3.02(2.82 ; 3.46)$ & $3.2(2.56 ; 3.68)$ & 0.759 \\
\hline Beta-alanine & $1.19(0.82 ; 1.61)$ & $2.9(1.8 ; 4.35)$ & 0.014 \\
\hline DL-5-hydroxylysine & $6.69(6.48 ; 6.77)$ & $6.67(6.56 ; 6.87)$ & 0.608 \\
\hline Ethanolamine & $18.77(14.52 ; 21.97)$ & $14.75(13.43 ; 16.43)$ & 0.104 \\
\hline L-2-aminobutyric acid & $5.97(1.97 ; 7.96)$ & $7.04(3.45 ; 10.51)$ & 0.255 \\
\hline L-alanine & $498.14(451.48 ; 554.51)$ & $426.72(390.15 ; 530.81)$ & 0.134 \\
\hline L-arginine & $55.2(42.7 ; 73.97)$ & $69.1(51.71 ; 81.33)$ & 0.23 \\
\hline L-asparagine & $46.5(43.4 ; 51)$ & $51.33(45.72 ; 53.85)$ & 0.404 \\
\hline L-aspartic acid & $21.69(12.05 ; 28.9)$ & $16.66(11.6 ; 26.76)$ & 0.753 \\
\hline L-carnosine & $2.14(1.93 ; 2.3)$ & $2.01(1.64 ; 2.33)$ & 0.274 \\
\hline L-citrulline & $11.92(10.83 ; 13.47)$ & $11.96(10.46 ; 15.18)$ & 0.357 \\
\hline L-cystathionine & $0.32(0.17 ; 0.46)$ & $0.2(0.16 ; 0.42)$ & 0.593 \\
\hline L-cystine & $28.93(26.49 ; 33.43)$ & $2.55(1.44 ; 3.81)$ & $<0.001$ \\
\hline L-glutamic acid & $138.44(41.01 ; 189.32)$ & $92.68(60.31 ; 109.28)$ & 0.187 \\
\hline L-glutamine & $617.36(576.47 ; 725.84)$ & 625.09 (559.72; 689.24) & 0.736 \\
\hline L-glycine & $277.25(255.67 ; 303.25)$ & $259.22(235.34 ;$ 293.13) & 0.43 \\
\hline L-histidine & $175.97(138.84 ; 206.4)$ & $141.92(103.55 ; 175.91)$ & 0.04 \\
\hline L-lysine & $410.97(388.38 ; 448.61)$ & $451.73(389.8 ; 488.91)$ & 0.531 \\
\hline L-methionine & $33.11(27.86 ; 39)$ & $30.61(25.81 ; 39.05)$ & 0.753 \\
\hline L-ornithine & 119.5 (100.28; 131.19) & 100.77 (83.6; 124.42) & 0.123 \\
\hline L-phenylalanine & $79.88(76.47 ; 94.87)$ & $80.5(75.99 ; 88.11)$ & 0.982 \\
\hline L-proline & $159.61(153.75 ; 177.18)$ & $158.5(143.86 ; 176.18)$ & 0.417 \\
\hline L-serine & $132.49(125.85 ; 148.56)$ & $143.03(128.45 ; 154.13)$ & 0.558 \\
\hline L-threonine & 293.9 (231.79; 339.82) & 319.48 (276.25; 352.53) & 0.23 \\
\hline L-tryptophan & 77.59 (66.69; 84.57) & 73.72 (68.93; 78.29) & 0.309 \\
\hline L-tyrosine & $70.65(57.22 ; 78.07)$ & $63.8(57.51 ; 77.25)$ & 0.685 \\
\hline Taurine & $38.01(31.1 ; 49.77)$ & $37.28(30.51 ; 46.92)$ & 0.928 \\
\hline Trans-4-hydroxy-L-proline & $20.95(17.68 ; 26.64)$ & $20.56(19.28 ; 23.57)$ & 0.893 \\
\hline
\end{tabular}

of experimental data made it possible to identify four amino acids, the levels of which were significantly different in patients with COVID-19 (Table 6; Fig. 3): 1-methylhistidine, beta-alanine, cystine, histidine.

As in case of amniotic fluid assay, logistic regression models were constructed, allowing us to distinguish cord blood plasma samples obtained from COVID-19 patients and controls. Results of the models' development and analysis are presented in Fig. 4, and Tables 7, 8. All the models constructed included cystine, obviously being the amino acid, which showed the greatest differences between groups. All the models were characterized by AUC of 1 , as well as by sensitivity and specificity of 1 (Table 8).

Of particular interest was the comparison of amino acids in amniotic fluid and cord blood plasma, which showed significant differences between the controls and the COVID-19 patients. Three amino acids were detected, and their levels were significantly different in COVID-19 patients simultaneously in two points (amniotic fluid and cord blood plasma), depicting the fetal metabolome in a holistic manner: 1-methylhistidine, cystine, and histidine (Table 9). 


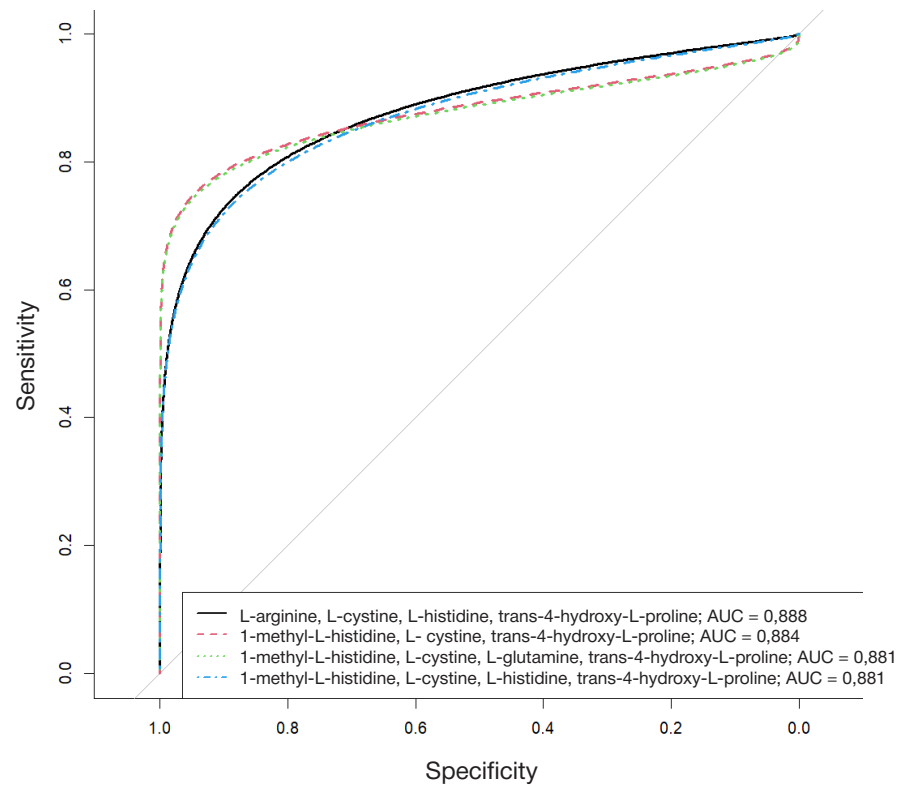

Fig. 2. ROC curves for logistic regression models constructed for classification of controls and COVID-19 patients based on amino acid concentrations in amniotic fluid

\section{DISCUSSION}

Viral infections cause characteristic changes in the host cell metabolism in order to ensure the effective replication of the virus [19]. Moreover, the resultant metabolic effects and cellular reprogramming vary between viruses (even within a single family) and host cell types.

The data obtained show significant differences in the concentrations of eight amino acids in amniotic fluid and four amino acids in cord blood plasma between the COVID-19 patients and the controls. Furthermore, concentrations of eight amino acids were reduced in COVID-19 patients. Similar amino acid concentration alterations were observed during assessment of blood plasma in children and adults with COVID-19 [24]. The authors of this study tried to confirm their hypothesis about the possible arginine concentration decrease

\section{A}

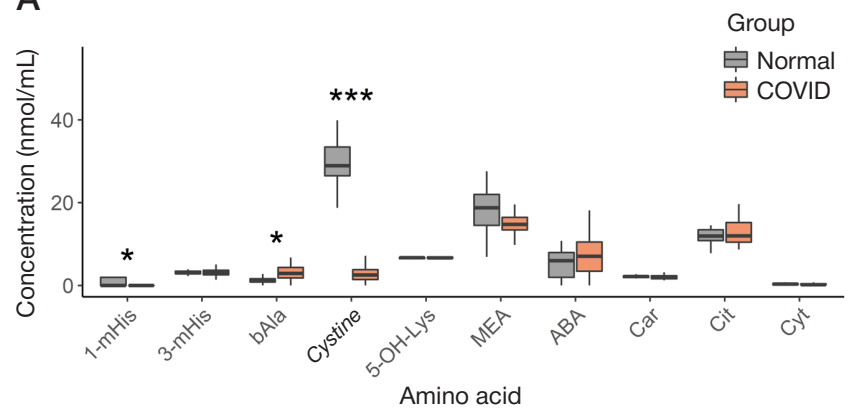

C in COVID-19 patients. It is known, that endothelial dysfunction contributes to lung damage associated with COVID-19 both in children and adults [27, 28]; low bioavailability of arginine is associated with endothelial dysfunction and T-cell dysregulation [29, 30], it also contributes to pathophysiology of numerous disorders [31]. Indeed, the expected decline in arginine concentration was observed in COVID-19 patients. Furthermore, the significantly reduced concentrations of citrulline, glutamine, alanine, glycine, histidine, proline, and some other amino acids were observed, however, the authors of the article had some difficulty explaining the mechanisms underlying the described effects [24]. The decreased amino acid concentrations were observed in individuals with a number of other disorders [19, 21-24, 32, 33].

In our study, of particular interest was the comparison of amino acid levels in amniotic fluid and cord blood plasma,
B

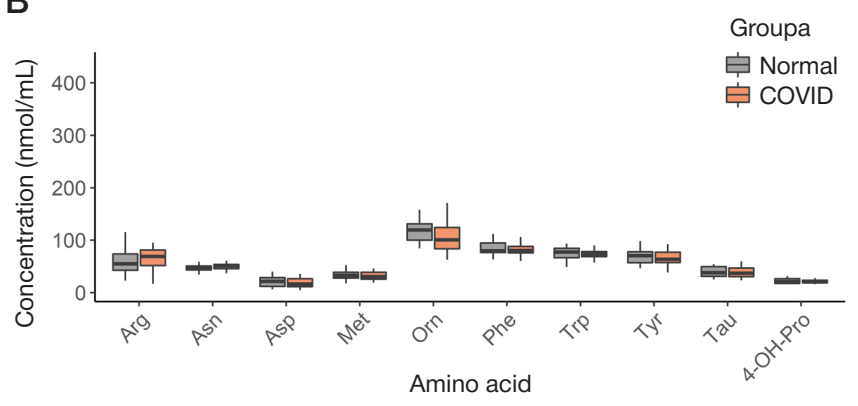

Group

官 Normal

官 COVID

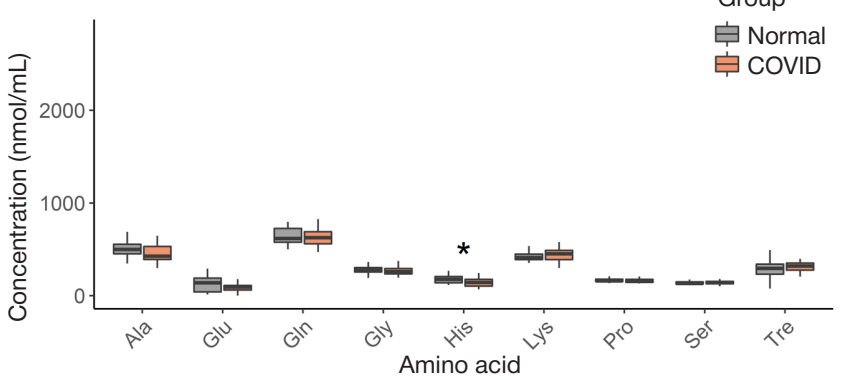

Fig. 3. Amino acid concentrations in cord blood plasma of controls and COVID-19 patients. The first and the third quartiles form the boundaries of the box, the median is shown as a line in the center of the box; the ends of whiskers represent the following: one and a half times interquartile range subtracted from the first quartile, sum of the third quartile and one and a half times interquartile range; ${ }^{*}-p \leq 0.05 ;{ }^{* *}-p \leq 0.01 ;{ }^{* *}-p \leq 0.001$. 1-mHis -1 -methylhistidine; 3-mHis - 3-methylhistidine; bAla - beta-alanine; BAIBA - 3-aminoisobutyric acid; 5-OH-Lys - 5-hydroxylysine; MEA - ethanolamine; ABA - 2-aminobutyric acid; AAD —-2-aminoadipic acid; Car - carnosine; Cit — citrulline; Cyt — cystathionine; 4-OH-Pro - 4-hydroxyproline 


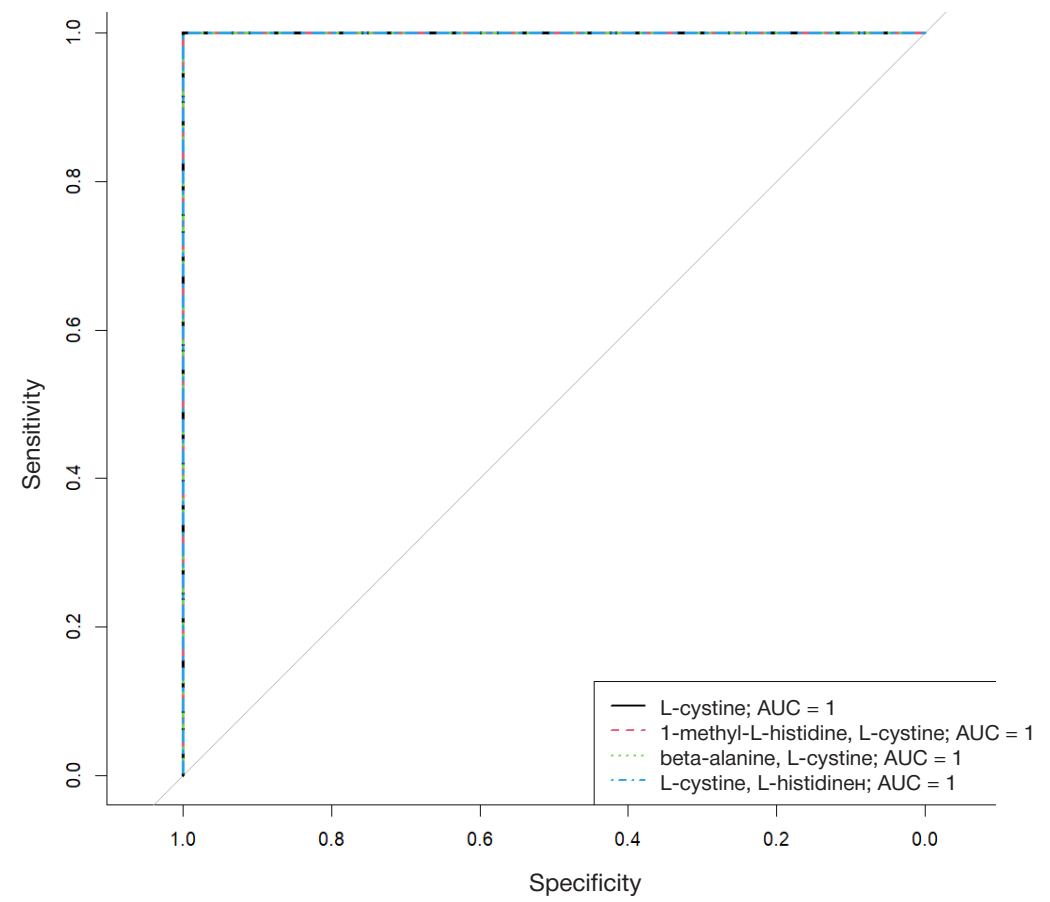

Fig. 4. ROC curves for logistic regression models constructed for classification of controls and COVID-19 patients based on amino acid concentrations in cord blood plasma which showed significant differences between the controls and the COVID-19 patients. Three amino acids were detected, and their levels were significantly different in COVID-19 patients simultaneously in two points (amniotic fluid and cord blood plasma), depicting the fetal metabolome in a holistic manner: 1-methylhistidine, cystine, and histidine.

L-cystine was one of the three amino acids detected in two fetal matrices at once (amniotic fluid and cord blood plasma),

having a high differentiating significance. L-cystine is a noncoded amino acid, being a derivative, obtained from oxidative dimerization of cysteine. During the post-translational modification of proteins, this amino acid plays a vital part in protein and peptide tertiary structure formation and maintaining, and, consequently, in their biological activity. Thus, such hormones as vasopressin, oxytocin, insulin, and somatostatin, acquire biological activity after the formation of intramolecular disulphide bonds.

Table 7. Parameters of logistic regression models allowing one to distinguish patients with COVID-19 from patients with no COVID-19 based on the amino acid concentrations in the cord blood plasma

\begin{tabular}{|c|c|c|c|c|}
\hline Model № & Coefficient & Coefficient value & Wald criterion & $p$-value \\
\hline \multirow{3}{*}{1} & Intercept term & 79.204 & 0.001 & 0.9992 \\
\cline { 2 - 5 } & L-cystine & -5.3827 & -0.001 & 0.9992 \\
\hline \multirow{3}{*}{2} & Intercept term & 79.4804 & 0.001 & 0.9992 \\
\cline { 2 - 5 } & 1-methyl-L-histidine & 3.1115 & $3.00 \mathrm{E}-04$ & 0.9998 \\
\cline { 2 - 5 } & L-cystine & -5.4032 & -0.001 & 0.9992 \\
\hline \multirow{3}{*}{3} & Intercept term & 77.8123 & $9.00 \mathrm{E}-04$ & 0.9992 \\
\cline { 2 - 5 } & Beta-alanine & -1.4597 & $-2.00 \mathrm{E}-04$ & 0.9998 \\
\cline { 2 - 5 } & L-cystine & -5.099 & -0.001 & 0.9992 \\
\hline \multirow{3}{*}{4} & Intercept term & 78.9156 & $9.00 \mathrm{E}-04$ & 0.9993 \\
\cline { 2 - 5 } & L-cystine & -5.3946 & -0.001 & 0.9992 \\
\hline
\end{tabular}

Table 8. Characteristics of logistic regression models allowing one to distinguish patients with COVID-19 from patients with no COVID-19 based on the amino acid concentrations in the blood cord plasma

\begin{tabular}{|l|c|c|c|c|}
\hline \multicolumn{1}{|c|}{ Amino acid } & AUC & Threshold & Sensitivity & Specificity \\
\hline L-cystine & 1 & 0.5 & $1(1 ; 1)$ & $1(1 ; 1)$ \\
\hline 1 -methyl-L-histidine, L-cystine & 1 & 0.5 & $1(1 ; 1)$ & $1(1 ; 1)$ \\
\hline Бета-аланин, L-cystine & 1 & 0.5 & $1(1 ; 1)$ & $1(1 ; 1)$ \\
\hline L-суstine, L- histidine & 1 & 0.5 & $1(1 ; 1)$ & $1(1 ; 1)$ \\
\hline
\end{tabular}


Table 9. Amino acid concentrations ( $\mathrm{nmol} / \mathrm{mL})$ in amniotic fluid and cord blood plasma showing significant differences between controls and COVID-19 patients

\begin{tabular}{|c|c|c|c|c|}
\hline Sample & Amino acid & Controls & COVID-19 & $p$-value \\
\hline \multirow{5}{*}{ Amniotic fluid } & 1-methyl-L-histidine & $9.52(5.78 ; 23.54)$ & $0(0 ; 4.98)$ & $<0.001$ \\
\cline { 2 - 5 } & 3-methyl-L-histidine & $7.44(6.38 ; 9.22)$ & $5.48(4.4 ; 6.17)$ & 0.002 \\
\cline { 2 - 5 } & L-arginine & $26.59(22.42 ; 48.86)$ & $16.25(8.97 ; 23.61)$ & 0.006 \\
\cline { 2 - 5 } & L-cystathionine & $0.96(0.83 ; 1.16)$ & $0.8(0.56 ; 0.96)$ & 0.036 \\
\cline { 2 - 5 } & L-cystine & $39.69(30.93 ; 46.09)$ & $15.92(5.48 ; 35.06)$ & 0.005 \\
\cline { 2 - 5 } & L-glutamine & $392.48(267.94 ; 450.24)$ & $286.57(177.62 ; 369.67)$ & 0.044 \\
\cline { 2 - 5 } & L-histidine & $65.35(34.72 ; 85.64)$ & $7.9(0 ; 30.68)$ & 0.008 \\
\hline \multirow{5}{*}{ Cord blood plasma } & Trans-4-hydroxy-L-proline & $18.03(14.18 ; 20.08)$ & $13.54(11.05 ; 15.96)$ & 0.019 \\
\cline { 2 - 5 } & 1-methyl-L-histidine & $0(0 ; 1.95)$ & $0(0 ; 0)$ & 0.041 \\
\cline { 2 - 5 } & Beta-alanine & $1.19(0.82 ; 1.61)$ & $2.9(1.8 ; 4.35)$ & 0.014 \\
\cline { 2 - 5 } & L-cystine & $28.93(26.49 ; 33.43)$ & $2.55(1.44 ; 3.81)$ & $<0.001$ \\
\hline
\end{tabular}

There were two amino acids showing significant differences in the amniotic fluid and cord blood plasma levels in neonates born to mothers with COVID-19: L-histidine and its derivative, 1-methylhistidine.

L-histidine is a heterocyclic alpha-amino acid, one of 20 proteinogenic amino acids, and one of two conditionally essential amino acids (along with arginine). It was originally thought to be essential only for children. Histidine residue is a part of active sites of numerous enzymes. Histidine is a precursor of histamine. Histamine plays an important role in inflammation and a number of allergic reactions. Histidine is one of the essential amino acids; it promotes tissue growth and regeneration, and contributes to red blood cell and white blood cell production, as well as to formation of the nerve cell myelin sheaths. Histidine deficiency may result in hearing loss, as well as in degenerative disorders, such as Parkinson's disease and Alzheimer's disease.

Our results demonstrate that the virus can cause major changes in metabolome of amniotic fluid and cord blood plasma, which risks the impaired programming of protein production. However, COVID-19 is often dormant at birth. Metabolic pathway alterations, resulting from violation of required amino acid ratio in the territory of the fetus, could be associated with replication of the virus, host inflammatory response, and altered energy metabolism. Probably, such metabolomic alterations may show up at the time of delivery, however, these have not been observed during our study due to the index group inclusion criteria. All puerperant women had COVID-19 at the time of delivery. May be that was the fact that prevented the virus to realize its entire harmful potential in the territory of the fetus.

\section{References}

1. Mendez-Figueroa H, Raker C, Anderson BL. Neonatal characteristics and outcomes of pregnancies complicated by influenza infection during the 2009 pandemic. American Journal of Obstetrics and Gynecology. 2011; 204 (6 SUPPL.): 58.

2. Song JY, Park KV, Han SW, Choi MJ, Noh JY, Cheong HJ, et al. Paradoxical long-term impact of maternal influenza infection on neonates and infants. BMC Infect Dis. 2020; 20 (1): 1-8.

3. Zeng L, Xia S, Yuan W, Yan K, Xiao F, Shao J, et al. Neonatal Early-Onset Infection with SARS-CoV-2 in 33 Neonates Born to Mothers with COVID-19 in Wuhan, China. JAMA Pediatr. 2020; 174 (7): 722-5

4. Yu N, Li W, Kang Q, Zeng W, Feng L, Wu J. No SARS-CoV-2 detected in amniotic fluid in mid-pregnancy. Lancet Infect Dis. 2020. DOI: 10.1016/S1473-3099(20)30320-0.

\section{CONCLUSION}

During the study we used the targeted metabolomics approach for detection of altered amino acid concentrations in pregnant women with COVID-19 infection upon admission to hospital. No such alterations were revealed. It was found that there were significant differences in concentrations of eight amino acids in amniotic fluid (1-methylhistidine, 3-methylhistidine, arginine, cystathionine, cystine, glutamine, histidine, trans-4hydroxyproline), and four amino acids in cord blood plasma (1-methylhistidine, beta-alanine, cystine, histidine) between the COVID-19 patients and the control group. Our aim was not only to find the markers of the disease, but also to understand the effect of COVID-19 infection of the fetal metabolome. It turns out, that the impaired metabolism of the amino acids detected shows up in individuals with a number of severe disorders, such as acute respiratory distress syndrome with severe sepsis, H1N1-associated pneumonia, bacterial pneumonia, sickle cell anemia, thalassemia, malaria, acute asthma, cystic fibrosis, pulmonary hypertension, cardiovascular disorders, certain cancer types, etc. These results may be used for selection of the areas for further investigation of possible health consequences in neonates born to mothers with COVID-19, as well as to define the requirements for treatment and medical care of pregnant women and newborns after COVID-19 diagnosis, since the long-term health consequences in this cohort of newborns may include endocrine, nervous system and allergic disorders, resulting from metabolomic impairments of protein production programming during the antenatal period.
5. Chen H, Guo J, Wang C, Luo F, Yu X, Zhang W, et al. Clinical characteristics and intrauterine vertical transmission potential of COVID-19 infection in nine pregnant women: a retrospective review of medical records. Lancet. 2020; 395 (10226): 809-15.

6. Zamaniyan M, Ebadi A, Aghajanpoor S, Rahmani Z, Haghshenas M, Azizi S. Preterm delivery, maternal death, and vertical transmission in a pregnant woman with COVID-19 infection. Prenat Diagn. 2020; 40 (13): 1759-61.

7. Sisman J, Jaleel MA, Moreno W, Rajaram V, Collins RRJ, Savani RC et al. Intrauterine Transmission of SARS-COV-2 Infection in a Preterm Infant. Pediatr Infect Dis J. 2020; 265-7.

8. Costa S, Posteraro B, Marchetti S, Tamburrini E, Carducci B, Lanzone $\mathrm{A}$, et al. Excretion of SARS-CoV-2 in human breast milk. Clin Microbiol Infect. 2020; 26 (10): 1430-2. 
9. Buonsenso D, Costa S, Sanguinetti M, Cattani P, Posteraro B, Marchetti $S$, et al. Neonatal Late Onset Infection with Severe Acute Respiratory Syndrome Coronavirus 2. Am J Perinatol. 2020; 37 (8): 869-72.

10. Qiancheng X, Jian S, Lingling P, Lei H, Xiaogan J, Weihua L, et al. Coronavirus disease 2019 in pregnancy. Int J Infect Dis. 2020; 95: 376-83.

11. Dong L, Tian J, He S, Zhu C, Wang J, Liu C, et al. Possible Vertical Transmission of SARS-CoV-2 from an Infected Mother to Her Newborn. JAMA. 2020; 323 (18): 1846-8.

12. Zhu H, Wang L, Fang $C$, Peng S, Zhang L, Chang G, et al. Clinical analysis of 10 neonates born to mothers with 2019-nCoV pneumonia. Transl Pediatr. 2020; 9 (1): 51-60.

13. Zeng $\mathrm{H}, \mathrm{Xu} \mathrm{C}$, Fan J, Tang $\mathrm{Y}$, Deng Q, Zhang W, et al. Antibodies in Infants Born to Mothers with COVID-19 Pneumonia. JAMA 2020; 323 (18):1848-9.

14. Sukhikh G, Petrova U, Prikhodko A, Starodubtseva N, Chingin K Chen $\mathrm{H}$, et al. Vertical Transmission of SARS-CoV-2 in Second Trimester Associated with Severe Neonatal Pathology. Viruses. 2021; 13 (3). DOI: 10.3390/v13030447.

15. Ellington $\mathrm{S}$, Strid $\mathrm{P}$, Tong VT, Woodworth $\mathrm{K}$, Galang RR, Zambrano $\mathrm{LD}$, et al. Characteristics of women of reproductive age with laboratory-confirmed SARS-COV-2 infection by pregnancy status United States, January 22-June 7, 2020. Morb Mortal Wkly Rep. 2020; 69 (25): 769-75.

16. Vivanti AJ, Vauloup-Fellous C, Prevot S, Zupan V, Suffee C, Do Cao J, et al. Transplacental transmission of SARS-CoV-2 infection. Nat Commun. 2020; 11 (1). DOl: 10.1038/s41467-020-17436-6.

17. Kell DB, Oliver SG. The metabolome 18 years on: a concept comes of age. Metabolomics. 2016; 12 (10). DOI: 10.1007/ s11306-016-1108-4

18. Shen B, Yi X, Sun $Y, B i X$, Du J, Zhang $C$, et al. Proteomic and Metabolomic Characterization of COVID-19 Patient Sera. Cell. 2020; 182 (1): 59-72.e15.

19. Wannemacher RW, Pekarek RS, Bartelloni PJ, Vollmer RT, Beisel WR. Changes in individual plasma amino acids following experimentally induced sand fly fever virus infection. Metabolism. 1972; 21 (1): 67-76.

20. Banoei MM, Vogel HJ, Welije AM, Kumar A, Yende S, Angus DC, et al. Plasma metabolomics for the diagnosis and prognosis of H1N1 influenza pneumonia. 2017; 1-15. DOI: 10.1186/s13054017-1672-7

21. Inoue S, Ikeda H. Differences in plasma amino acid levels in patients with and without bacterial infection during the early stage

\section{Литература}

1. Mendez-Figueroa H, Raker C, Anderson BL. Neonatal characteristics and outcomes of pregnancies complicated by influenza infection during the 2009 pandemic. American Journa of Obstetrics and Gynecology. 2011; 204 (6 SUPPL.): 58.

2. Song JY, Park KV, Han SW, Choi MJ, Noh JY, Cheong HJ, et al. Paradoxical long-term impact of maternal influenza infection on neonates and infants. BMC Infect Dis. 2020; 20 (1): 1-8.

3. Zeng L, Xia S, Yuan W, Yan K, Xiao F, Shao J, et al. Neonatal Early-Onset Infection with SARS-CoV-2 in 33 Neonates Born to Mothers with COVID-19 in Wuhan, China. JAMA Pediatr. 2020; 174 (7): 722-5.

4. Yu N, Li W, Kang Q, Zeng W, Feng L, Wu J. No SARS-CoV-2 detected in amniotic fluid in mid-pregnancy. Lancet Infect Dis. 2020. DOI: 10.1016/S1473-3099(20)30320-0.

5. Chen H, Guo J, Wang C, Luo F, Yu X, Zhang W, et al. Clinical characteristics and intrauterine vertical transmission potential of COVID-19 infection in nine pregnant women: a retrospective review of medical records. Lancet. 2020; 395 (10226): 809-15.

6. Zamaniyan M, Ebadi A, Aghajanpoor S, Rahmani Z, Haghshenas M, Azizi S. Preterm delivery, maternal death, and vertical transmission in a pregnant woman with COVID-19 infection. Prenat Diagn. 2020; 40 (13): 1759-61.

7. Sisman J, Jaleel MA, Moreno W, Rajaram V, Collins RRJ, Savani RC, et al. Intrauterine Transmission of SARS-COV-2 Infection in a Preterm Infant. Pediatr Infect Dis J. 2020; 265-7. of acute exacerbation of COPD. Int J COPD. 2019; 14: 575-83.

22. Moat SJ, George RS, Carling RS. Use of Dried Blood Spot Specimens to Monitor Patients with Inherited Metabolic Disorders Int J Neonatal Screen. 2020; 6 (2): 1-17.

23. Páez-Franco JC, Torres-Ruiz J, Sosa-Hernández VA, CervantesDíaz R, Romero-Ramírez S, Pérez-Fragoso A, et al. Metabolomics analysis reveals a modified amino acid metabolism that correlates with altered oxygen homeostasis in COVID-19 patients. Sci Rep. 2021; 11 (1). DOI: 10.1038/s41598-021-85788-0.

24. Rees CA, Rostad CA, Mantus G, Anderson EJ, Chahroudi A Jaggi P. Altered amino acid profile in patients with SARS-CoV-2 infection. 2021; 118 (25): 4-6.

25. Hirschel J, Vogel M, Baber R, Garten A, Beuchel C, Dietz Y, et al. Relation of whole blood amino acid and acylcarnitine metabolome to age, sex, BMl, puberty, and metabolic markers in children and adolescents. Metabolites. 2020; 10 (4). DOI: 10.3390/ metabo10040149.

26. Thaker SK, Chng J, Christofk HR. Viral hijacking of cellular metabolism. BMC Biol. 2019; 17 (1): 59.

27. Diorio C, McNerney KO, Lambert M, Paessler M, Anderson EM, Henrickson SE, et al. Evidence of thrombotic microangiopathy in children with SARS-CoV-2 across the spectrum of clinical presentations. Blood Adv. 2020; 4 (23): 6051-63.

28. Tay MZ, Poh CM, Rénia L, MacAry PA, Ng LFP. The trinity of COVID-19: immunity, inflammation and intervention. Nature Reviews Immunology. 2020; 20 (6): 363-74.

29. Gambardella J, Khondkar W, Morelli MB, Wang X, Santulli G, Trimarco V. Arginine and endothelial function. Biomedicines. 2020; 8 (8): 277.

30. Rodríguez PC, Ochoa AC. Arginine regulation by myeloid derived suppressor cells and tolerance in cancer: Mechanisms and therapeutic perspectives. Immunological Reviews. 2008; 222 (1): 180-91.

31. Morris CR, Hamilton-Reeves J, Martindale RG, Sarav M, Ochoa Gautier JB. Acquired Amino Acid Deficiencies: A Focus on Arginine and Glutamine. In: Nutrition in Clinical Practice. SAGE Publications Inc.: 2017; 30S-47S.

32. IKEDA H. Plasma amino acid levels in individuals with bacterial pneumonia and healthy controls. 2020; 1-17. DOI: 10.21203/ rs.3.rs-18796/v1

33. Ware LB, Magarik JA, Wickersham N, Cunningham G, Rice TW, Christman BW, et al. Low plasma citrulline levels are associated with acute respiratory distress syndrome in patients with severe sepsis. Crit Care. 2013; 17 (1): 1-8.

8. Costa S, Posteraro B, Marchetti S, Tamburrini E, Carducci B Lanzone A, et al. Excretion of SARS-CoV-2 in human breast milk. Clin Microbiol Infect. 2020; 26 (10): 1430-2.

9. Buonsenso D, Costa S, Sanguinetti M, Cattani P, Posteraro B, Marchetti S, et al. Neonatal Late Onset Infection with Severe Acute Respiratory Syndrome Coronavirus 2. Am J Perinatol. 2020; 37 (8): 869-72.

10. Qiancheng X, Jian S, Lingling P, Lei H, Xiaogan J, Weihua L, et al. Coronavirus disease 2019 in pregnancy. Int J Infect Dis. 2020; 95: 376-83

11. Dong L, Tian J, He S, Zhu C, Wang J, Liu C, et al. Possible Vertical Transmission of SARS-CoV-2 from an Infected Mother to Her Newborn. JAMA. 2020; 323 (18): 1846-8.

12. Zhu $H$, Wang $L$, Fang $C$, Peng $S$, Zhang $L$, Chang $G$, et al. Clinical analysis of 10 neonates born to mothers with 2019-nCoV pneumonia. Transl Pediatr. 2020; 9 (1): 51-60.

13. Zeng $\mathrm{H}, \mathrm{Xu} \mathrm{C}$, Fan J, Tang $\mathrm{Y}$, Deng Q, Zhang W, et al. Antibodies in Infants Born to Mothers with COVID-19 Pneumonia. JAMA. 2020; 323 (18):1848-9.

14. Sukhikh G, Petrova U, Prikhodko A, Starodubtseva N, Chingin K, Chen $\mathrm{H}$, et al. Vertical Transmission of SARS-CoV-2 in Second Trimester Associated with Severe Neonatal Pathology. Viruses. 2021; 13 (3). DOI: 10.3390/v13030447.

15. Ellington S, Strid P, Tong VT, Woodworth $K$, Galang RR, Zambrano LD, et al. Characteristics of women of reproductive age with 
laboratory-confirmed SARS-COV-2 infection by pregnancy status United States, January 22-June 7, 2020. Morb Mortal Wkly Rep. 2020; 69 (25): 769-75.

16. Vivanti AJ, Vauloup-Fellous C, Prevot S, Zupan V, Suffee C, Do Cao J, et al. Transplacental transmission of SARS-CoV-2 infection. Nat Commun. 2020; 11 (1). DOI: 10.1038/s41467-020-17436-6.

17. Kell DB, Oliver SG. The metabolome 18 years on: a concept comes of age. Metabolomics. 2016; 12 (10). DOI: 10.1007/ s11306-016-1108-4.

18. Shen B, Yi X, Sun Y, Bi X, Du J, Zhang C, et al. Proteomic and Metabolomic Characterization of COVID-19 Patient Sera. Cell. 2020; 182 (1): 59-72.e15.

19. Wannemacher RW, Pekarek RS, Bartelloni PJ, Vollmer RT, Beisel WR. Changes in individual plasma amino acids following experimentally induced sand fly fever virus infection. Metabolism. 1972; 21 (1): 67-76.

20. Banoei MM, Vogel HJ, Weljie AM, Kumar A, Yende S, Angus DC, et al. Plasma metabolomics for the diagnosis and prognosis of H1N1 influenza pneumonia. 2017; 1-15. DOI: 10.1186/s13054017-1672-7

21. Inoue S, Ikeda $\mathrm{H}$. Differences in plasma amino acid levels in patients with and without bacterial infection during the early stage of acute exacerbation of COPD. Int J COPD. 2019; 14: 575-83.

22. Moat SJ, George RS, Carling RS. Use of Dried Blood Spot Specimens to Monitor Patients with Inherited Metabolic Disorders. Int J Neonatal Screen. 2020; 6 (2): 1-17.

23. Páez-Franco JC, Torres-Ruiz J, Sosa-Hernández VA, CervantesDíaz R, Romero-Ramírez S, Pérez-Fragoso A, et al. Metabolomics analysis reveals a modified amino acid metabolism that correlates with altered oxygen homeostasis in COVID-19 patients. Sci Rep. 2021; 11 (1). DOI: 10.1038/s41598-021-85788-0.

24. Rees CA, Rostad CA, Mantus G, Anderson EJ, Chahroudi A, Jaggi P. Altered amino acid profile in patients with SARS-CoV-2 infection. 2021; 118 (25): 4-6.

25. Hirschel J, Vogel M, Baber R, Garten A, Beuchel C, Dietz Y, et al. Relation of whole blood amino acid and acylcarnitine metabolome to age, sex, BMI, puberty, and metabolic markers in children and adolescents. Metabolites. 2020; 10 (4). DOI: 10.3390/ metabo10040149.

26. Thaker SK, Chng J, Christofk HR. Viral hijacking of cellular metabolism. BMC Biol. 2019; 17 (1): 59.

27. Diorio C, McNerney KO, Lambert M, Paessler M, Anderson EM, Henrickson SE, et al. Evidence of thrombotic microangiopathy in children with SARS-CoV-2 across the spectrum of clinical presentations. Blood Adv. 2020; 4 (23): 6051-63.

28. Tay MZ, Poh CM, Rénia L, MacAry PA, Ng LFP. The trinity of COVID-19: immunity, inflammation and intervention. Nature Reviews Immunology. 2020; 20 (6): 363-74.

29. Gambardella J, Khondkar W, Morelli MB, Wang X, Santulli G, Trimarco V. Arginine and endothelial function. Biomedicines. 2020; 8 (8): 277.

30. Rodríguez PC, Ochoa AC. Arginine regulation by myeloid derived suppressor cells and tolerance in cancer: Mechanisms and therapeutic perspectives. Immunological Reviews. 2008; 222 (1): 180-91.

31. Morris CR, Hamilton-Reeves J, Martindale RG, Sarav M, Ochoa Gautier JB. Acquired Amino Acid Deficiencies: A Focus on Arginine and Glutamine. In: Nutrition in Clinical Practice. SAGE Publications Inc.: 2017; 30S-47S.

32. IKEDA H. Plasma amino acid levels in individuals with bacterial pneumonia and healthy controls. 2020; 1-17. DOI: 10.21203/ rs.3.rs-18796/v1.

33. Ware LB, Magarik JA, Wickersham N, Cunningham G, Rice TW, Christman BW, et al. Low plasma citrulline levels are associated with acute respiratory distress syndrome in patients with severe sepsis. Crit Care. 2013; 17 (1): 1-8. 